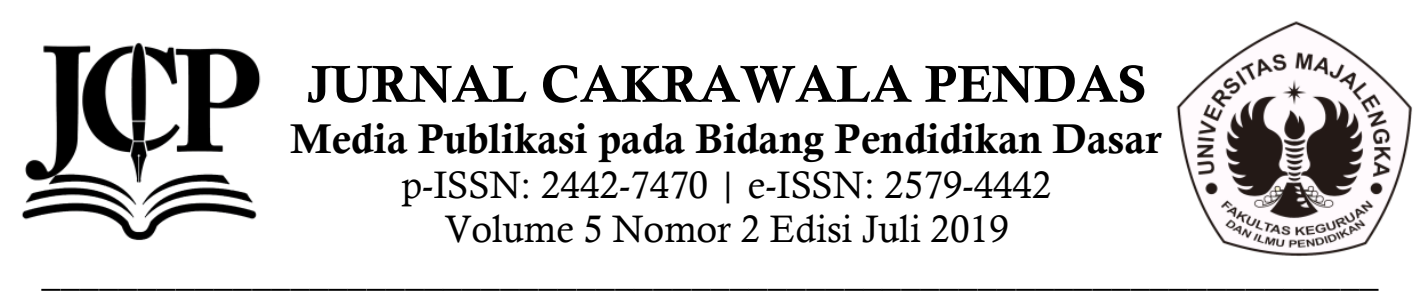

\title{
Menumbuhkan Kepemimpinan Anak di Sekolah Dasar
}

\author{
Roni Rodiyana ${ }^{1}$, Wina Dwi Puspitasari ${ }^{2}$ \\ ${ }^{1,2}$ PGSD FKIP Universitas Majalengka \\ E-mail: 마ronirodiyana@unma.ac.id, ${ }^{2}$ winad1211@unma.ac.id
}

\begin{abstract}
Abstrak
Kepemimpinan adalah tanggung jawab semua orang termasuk anak sekolah dasar. Kontribusi yang paling penting untuk setiap pendidik adalah mengidentifikasi dan mengembangkan sikap kepemimpinan pada anak-anak. Guru sekolah dasar berpeluang untuk menanamkan jiwa kepemimpinan ke dalam kelas, pentingnya menanamkan dan mengasah jiwa kepemimpinan sejak dini, bertujuan untuk menyiapkan generasi-generasi terbaik di masa yang akan datang. Generasi yang akan menggantikan generasi tua untuk melanjutkan tugas mengisi kemerdekaan dan pembangunan. Generasi yang siap untuk menghadapi setiap tantangan yang akan datang di masa depan kelak.
\end{abstract}

Kata kunci: Kepemimpinan, Sekolah Dasar 


\section{Pendahuluan}

\section{Latar Belakang}

Kepemimpinan merupakan salah satu topik yang selalu menarik untuk dikaji dan diteliti, karena paling banyak diamati sekaligus fenomena yang paling sedikit dipahami. Permasalahannya ialah dinamika itu menuju kearah perbaikan ataukah kearah kemunduran. Untuk antisipasi kearah kemunduran perlu diupayakan upaya antisipatif yaitu dengan adanya pendidikan kepemimpinan dari sejak dini, khususnya di sekolah dasar sebagai pendidikan formal yang pertama. Dalam Hadist (Al-Bukhori: 4789) "setiap orang adalah pemimpin", jadi bagaimana tugas kita menumbuhkan jiwa kepemimpinan pada anak-anak yang sudah mempunyai potensi leadership dari sejak dini itu.

Menjadi pemimpin yang baik adalah keterampilan yang berharga, tidak peduli berapa usia seseorang, apakah orang itu berada di sekolah atau tempat kerja. Seorang pemimpin harus memiliki kemampuan untuk berkomunikasi secara efektif dalam berbagai macam situasi, apakah dengan karyawan, konsumen, pelamar, atau masyarakat umum. Hilangnya komunikasi menyebabkan hilangnya produktivitas dan keyakinan. Itulah mengapa penting untuk mengajarkan anak-anak sejak dini, bagaimana mengembangkan keterampilan untuk menjadi pemimpin yang baik. Menjadi seorang pemimpin akan membantu anakanak membangun kepercayaan diri dan sukses dalam kegiatan seperti proyek kelompok, tim, klub, dan lain-lain, dan keterampilan ini akan menguntungkan mereka saat mereka tumbuh dewasa seperti tadi (Sondang, 1994).

Leadership atau kepemimpinan pada dasarnya dapat dibentuk dan dilatih sejak usia sekolah dasar, agar pada saatnya nanti ketika menghadapi beberapa permasalahan anak akan mudah menemukan solusi beberapa alernatif penyelesaian masalah tersebut. Untuk itu, bagi para pendidik mari kita belajar menerapkan bagaimana proses kepemimpinan bagi anak di sekolah dasar, karena leadership sangat penting untuk diterapkan dalam kehidupan anak, dikarenakan anak akan mempunyai semangat, serta mempunyai rasa tanggung jawab yang tinggi pada setiap amanah atau aktivitas yang sudah menjadi tanggung jawabnya. Dengan berjiwa pemimpin anakanak kelak akan dapat mempengaruhi orang-orang yang berada di sekitar anak, dapat bekerjasama demi mencapai tujuan, mengelola diri, kelompok dan lingkungan dengan baik, khususnya dalam penanggulangan masalah yang relatif pelik dan sulit.

2. Rumusan Masalah

Bagaimana cara orang tua/guru melatih atau mengembangakan keterampilan kepemimpinan pada anakanak di sekolah dasar?

3. Tujuan

Agar supaya orang tua/guru mampu memahami serta melatih atau mengembangakan keterampilan kepemimpinan pada anak-anak.

4. Manfaat

Manfaat dari mempelajari pendidikan kepemimpinan pada anak-anak, yaitu untuk mengetahui potensi kepemimpinan yang dimiliki anak, untuk merencanakan masa depan anak, dan untuk menentukan tugas atau kegiatan apa yang harus dilakukan oleh anak dalam mencapai masa depannya.

\section{Pembahasan}

Kepemimpinan adalah tanggung jawab semua orang karena perilaku setiap orang berpotensi mempengaruhi orang lain. Siswa sekolah dasar saat ini hidup di masa Google, usia transparansi teknologi dan interpersonal, dimana siswa tidak akan memiliki informasi yang kurang, sebaliknya siswa akan mampu melakukan akselerasi ilmu pengetahuan yang tidak terbayangkan oleh orang tua ataupun pendidiknya. Prestasi di abad ke-21 akan tergantung pada kemampuan seseorang untuk memimpin, untuk berkembang dalam sistem jaringan yang lebih luas, lebih bervariasi, dan lebih terbuka dari pada waktu sebelumnya dalam sejarah manusia (Seidman, 2007: 55). Inti pelajaran kepemimpinan untuk siswa SD adalah kegiatan menghormati dan saling mempercayai, serta membuat koneksi emosional dan komitmen untuk menyelesaikan tugas-tugas.

Dalam kehidupan di kelas, penting bagi siswa SD untuk merasakan atmosfer 
kepemimpinan, dimana guru harus memberikan kesempatan yang menjanjikan bagi siswa untuk memperbesar konsepsi kepemimpinan mereka dengan menghubungkan emosi dirinya sendiri dengan gairah untuk melayani teman sebaya, disiplin dalam mendengarkan pendapat guru ataupun teman sebayanya, dan berani dalam bertanya. Pelajaran bagi siswa sebagai calon pemimpin adalah bagaimana cara guru memperbesar keinginan anak untuk memicu rasa ingin tahu orang lain. Mendengarkan dengan rasa ingin tahu adalah tindakan kreatif yang paling kuat yang dapat dilakukan, karena mendengarkan adalah pintu dimana anak membiarkan dunia luar untuk masuk (Ellinor \& Gerard, 1998: 99). Kegiatan mendengarkan dapat meningkatkan komunikasi interpersonal, memperkuat keterampilan anak, menciptakan makna bersama, mengembangkan kemitraan bersama, dan berpartisipasi dalam kegiatan kepemimpinan bersama di dalam kelas ataupun di sekolah (Wiersma, 2010: 237).

Pemecahan masalah, imajinasi, dan perilaku prososial adalah aspek kepemimpinan yang dapat dipelajari pada anak sekolah dasar. Karena sikap percaya diri, sikap terhadap belajar, dan keterampilan sosial berkembang dalam enam tahun pertama kehidupan anak. Penting bagi guru untuk memahami bagaimana mengembangkan kepemimpinan dan perilaku prososial anak. Anak perlu diperhatikan secara khusus dalam mencapai potensi kepemimpinan mereka. Anak-anak biasanya sering didorong oleh orang tua mereka untuk unggul di bidang akademik, seperti mereka harus dapat membaca awal, memiliki kosakata yang banyak, dan mampu memecahkan masalah matematika. Tapi hal seperti itu bukan prioritas kebutuhan anak, anak harus diberikan kegiatan pembelajaran yang dapat mengembangkan sikap kepemimpinan mereka di sekolah, karena anak memiliki kecerdasan untuk memberikan kepemimpinan, dan mereka juga harus mengembangkan keterampilan sosial yang efektif dalam rangka untuk mengambil posisi kepemimpinan dimasa yang akan datang.
Karakteristik terbaik dari seorang pemimpin adalah bahwa ia memahami dasar-dasar. Dia tidak akan ragu-ragu ketika mengambil bagian dalam pekerjaan. Belajar dari pengalamannya sendiri adalah pelajaran yang sangat penting dari seorang pemimpin. Pemimpin memiliki pengetahuan, sehingga orang tua/guru juga harus mendorong anak untuk membaca koran dan buku secara teratur. Membaca dapat menjadi sumber inspirasi bagi calon pemimpin. Mengajar anak untuk menetapkan tujuan dan standar yang tinggi, ini tidak berarti memaksa anak untuk mencapai hal yang mustahil, tetapi mengajarinya untuk selalu mempunyai tujuan yang baik dan yang lebih penting, mengajarinya bagaimana mencapai tujuan tersebut.

Apa yang membuat belajar kepemimpinan penting hari ini? Ini adalah kenyataan bahwa ada banyak situasi saat ini ketika kita mendapatkan pekerjaan dan harus mengambil peran jadi pemimpin didalamnya. Ini juga berlaku bagi anakanak, dengan adanya banyak kegiatan di sekolah, debat, olahraga, dan lain-lain, ada kalanya anak diminta untuk memimpin grup/tim tersebut, maka dari sejak dini orang tua/guru harus memberikan stimulus, seperti pergi ke depan dan mengajarkan anak tentang kepemimpinan, hal ini dapat menjadi momen yang sangat membanggakan bagi orang tua/guru ketika ia akhirnya menjadi seorang pemimpin besar di suatu saat nanti.

Penjelasan di atas memberikan gambaran kepada kita, bahwasannya keterampilan kepemimpinan sangat penting untuk diterapkan dari sejak dini. Ada sejumlah cara untuk mengembangkan keterampilan kepemimpinan pada anakanak, diantaranya yaitu:

1. Membantu mereka belajar untuk melihat sudut pandang yang berbeda dalam situasi kelompok dimana terdapat pendapat yang variatif.

Seorang pemimpin yang baik tidak menyatakan dirinya seorang pemimpin, tetapi dipilih oleh rekan-rekannya untuk menjadi seorang pemimpin. Dengan demikian, tujuan akhirnya adalah untuk tidak mengajar anak bagaimana menjadi seorang pemimpin, tetapi untuk 
mengajarinya dasar etika dan nilai-nilai sehingga ia menjadi individu yang kuat dengan kemampuan untuk menjadi seorang pemimpin. Anak-anak dapat diajarkan keterampilan kepemimpinan di usia dini karena pikiran mereka masih muda, ingin tahu dan waspada untuk sebuah identitas. Dengan bimbingan guru anak juga akan belajar bagaimana berkomunikasi secara efektif, strategi, menangani situasi rumit, tidak ditekan, dan merencanakan segala sesuatu di awal. Pemimpin adalah orang yang paling proaktif dalam setiap kelompok sehingga guru harus mengajarinya untuk selalu mengambil inisiatif. Tampilkan dia dengan contoh-contoh kehidupan nyata bagaimana disiplin dan bersikap proaktif, karena hal tersebut dapat membuat anak menonjol dan menjadi sukses (Elmore, 2001).

2. Membantu

mereka

mempertahankan sikap positif ketika orang lain membuat hal-hal sulit atau mengatakan bahwa mereka tidak dapat mencapai sesuatu.

Menurut Yukl (2010: 45), salah satu ciri yang paling penting dari seorang pemimpin adalah kemampuan untuk membuat keputusan untuk diri sendiri, mampu berdiri dari tekanan teman sebaya dan menetapkan standar perilaku pribadi. Seorang pemimpin tetap fokus dalam mempertahankan sikap positifnya, walaupun orang disekitar mereka mengatakan tidak. Ajarkan anak untuk mengatakan "ya saya bisa!" bahkan ketika mereka tidak yakin, "ini bukan masalah, itu adalah tantangan!", "jangan pernah menyerah, tidak pernah menyerah", "saya mungkin gagal atau membuat kesalahan tapi saya selalu belajar dan bergerak maju", "apa yang bisa saya pelajari dari pengalaman ini", "aku akan selalu melakukan yang terbaik", ajarkan anak kekuatan dan pentingnya untuk tidak berhenti dan memenuhi komitmen mereka dalam kehidupan.

3. Ajarkan mereka bahwa kesalahan akan selalu terjadi dan merupakan bagian alami dari kehidupan, dan tidak membiarkan kesalahan mengalahkan semangat mereka untuk lebih baik lagi. Sebaliknya, ajarkan kepada mereka untuk bertanya pada diri sendiri apa yang bisa dilakukan untuk menghadapi situasi yang sulit itu.

Siswa sering mengukur kecerdasan dan keberhasilan mereka di sekolah dengan nilai ujian dan nilai pekerjaan rumah. Anak yang memiliki kecerdasan bawaan mungkin menjadi lebih frustrasi dalam menghadapi kegagalan, sehingga menyebabkan mereka menghindari berbagai tantangan. Ini bisa sulit bagi anak-anak untuk melihat kesalahan mereka sebagai hal yang positif, anak-anak begitu takut gagal bahwa reaksi mereka terhadap nilai buruk dapat merugikan. Inilah sebabnya mengapa penting bagi orang tua/guru untuk tidak bereaksi berlebihan ketika anak memperoleh nilai buruk. Sampaikan kepada anak harus tetap tenang, masalah itu akan berlalu dan sampaikan bahwa nilai buruk tidak berarti mereka tidak cerdas. Mitchell (2011) memiliki beberapa tips bagi orang tua/guru dalam membantu anakanak belajar dari kesalahan, baik mereka di dalam ataupun di luar kelas, yaitu:

a. Menyampaikan bahwa Anda tidak mengharapkan anak-anak Anda untuk menjadi sempurna.

b. Jangan menyelamatkan anak-anak dari kesalahan mereka. Sebaliknya, bantu mereka fokus pada solusi.

c. Berikan contoh kesalahan Anda sendiri, dan bagaimana Anda belajar dari kesalahan itu.

d. Mendorong mereka untuk mengambil tanggung jawab atas kesalahan mereka dan tidak menyalahkan orang lain.

e. Hindari menunjukkan kesalahan masa lalu mereka.

f. Memuji mereka karena kemampuan mereka untuk mengakui kesalahan mereka.

g. Pujilah mereka atas upaya dan keberanian mereka untuk mengatasi kekeliruannya.

h. Bimbing mereka bagaimana meminta maaf atas kesalahan ketika mereka telah menyakiti orang lain.

i. Membantu mereka melihat sisi baik dari hal salah yang pernah dilakukan oleh mereka. 
j. Biarkan mereka membuat keputusan sendiri, supaya mereka belajar arti dari prinsip trial and error.

k. Ajarkan mereka untuk menetapkan tujuan dan selalu mencoba untuk melakukan yang terbaik dalam segala hal.

4. Mendaftarkan anak-anak dalam kegiatan ekstrakurikuler untuk memberikan mereka kepercayaan diri yang dibutuhkan dalam memimpin orang-orang.

Semua orang tua bermimpi anak mereka menjadi pemimpin besar di masa depan. Melihat anak tumbuh menjadi penting dan sukses dalam karir mereka adalah sesuatu yang setiap orang tua inginkan. Budidaya pemimpin masa depan, berarti harus menanamkan keterampilan kepemimpinan dari sejak dini. Menurut Elmore (2001), berikut adalah cara supaya anak memiliki keterampilan leadership, diantaranya yaitu:

a. Percaya diri, ini adalah salah satu keterampilan yang paling penting bagi seorang pemimpin di masa depan, tetapi tidak dapat diajarkan. Anak-anak belajar percaya diri tidak hanya melalui pujian, tetapi juga dengan memiliki kesempatan untuk melakukan pekerjaan yang baik. Mendaftarkan anak-anak dalam kegiatan ekstrakurikuler, seperti olahraga tim, olahraga individual, dan kegiatan lain seperti pramuka, ini adalah cara terbaik untuk menanamkan mereka rasa percaya diri akan pentingnya memimpin orang-orang atau organisasi.

b. Bekerja sama (teamwork), untuk mempunyai semangat atau jiwa sebagai seorang pemimpin, anak harus sering terlibat bekerjasama sebagai tim dalam suatu kegiatan atau aktivitas apapun. Ketika anak sering terlibat kerjasama (teamwork) maka dari kegiatan tersebut akan menghasilkan ide, pemikiran, saran, serta gagasan-gagasan agar tujuan dari kerjasama yang sebelumnya dapat segera diimplementasikan. Sebenarnya proses anak terlibat dalam sebuah teamwork bisa menghasilkan kualitas bakat untuk kriteria-kriteria yang diharapkan dari calon-calon pemimpin. Karena, proses teamwork tersebut pada dasarnya terdapat unsur-unsur komunikasi, diskusi, solusi, ide, pemikiran, serta pemecahan masalah yang nantinya akan sangat diperlukan dalam sebuah kerjasama.

5. Belajar bijaksana terhadap uang, mampu mengelola uang dengan baik sangat penting jika ingin anak menjadi seorang pemimpin disuatu hari nanti. Cara terbaik untuk mengajar anak adalah memberi mereka uang saku dan mempunyai buku tabungan baik di sekolah ataupun di bank, hal seperti ini dapat membantu mereka membuat keputusan tentang bagaimana membelanjakan dan menyimpan, sehingga mereka belajar arti nilai uang.

6. Pengambilan keputusan, para pemimpin yang baik harus mampu membuat keputusan yang baik. Memberikan anak kesempatan untuk membuat keputusan bagi diri mereka sendiri itu sangat penting. Mulailah dengan keputusan kecil, seperti membiarkan anak memilih pakaian mereka ketika mereka masih muda, memberikan kebebasan dalam mengambil keputusan supaya mereka memahami konsep tanggung jawab dan konsekuensi. Pemodelan keterampilan membuat keputusan yang baik dalam kehidupan seharihari juga penting, tapi jangan lupa untuk berbicara dengan anak tentang mengapa Anda membuat pilihan yang Anda lakukan, dan bagaimana konsekuensi bentuk keputusan yang kita buat.

7. Kegiatan berkebun di taman/sekolah, berikan anak beberapa pot tanaman, kemudian memeliharanya sampai tanaman itu tumbuh dan berkembang. Merupakan suatu 
kebanggaan apabila apa yang mereka tanam dan mereka rawat tumbuh dan berkembang. Tujuannya adalah membangun komitmen anak, dan menumbuhkan sikap tanggung jawab serta memberikan sifat-sifat kepemimpinan.

8. Membawa anak anda ke tempat kerja. Bagi orang tua tidak ada salahnya sewaktu-waktu membawa anaknya untuk bekerja, biarkan anak mengikuti mobilitas anda ketika sedang bekerja, hal ini supaya mereka tahu tentang cara-cara anda bekerja. pemodelan ini akan memberi mereka kesempatan untuk melihat pilihan karir, serta melihat anda sebagai orang yang sangat kerja keras (Kessie, 2016).

9. Pembinaan agama, pembinaan agama yang dilakukan orang tua terhadap anak mempunyai banyak manfaat bagi kehidupan mereka, salah satunya yaitu mampu menjadi sosok pribadi yang bijaksana yang tentu saja dibutuhkan oleh figur pemimpin.

Itulah penjelasan mengenai cara memberikan treatment kepada anak supaya mereka mendapatkan pembelajaran dan pengalaman, serta dapat menginternalisasi sikap kepemimpinan dari sejak dini, karena sikap kepemimpinan sangat erat hubungannya dengan karir anak dimasa yang akan datang. Harapannya adalah orang tua dan guru tidak boleh lelah dalam memberikan pembelajaran kepada anak, serta selalu memberikan role model setiap hari, anak adalah aset bangsa dan regenerasi kita dikemudian hari, tingkatkan dan kembangkan potensi mereka karena hal itu menjadi kebahagiaan kita bersama.

\section{Simpulan dan Saran}

1. Simpulan

Penting bagi orang tua/guru untuk memahami bagaimana mengembangkan kepemimpinan anak. Inti pelajaran kepemimpinan untuk siswa sekolah dasar adalah kegiatan menghormati dan saling mempercayai, serta membuat koneksi emosional dan komitmen untuk menyelesaikan tugas-tugas. Ada sejumlah cara untuk mengembangkan keterampilan kepemimpinan pada anak-anak, diantaranya yaitu: 1) membantu mereka belajar untuk melihat sudut pandang yang berbeda dalam situasi kelompok dimana terdapat pendapat yang variatif; 2) membantu mereka mempertahankan sikap positif ketika orang lain membuat hal-hal sulit atau mengatakan bahwa mereka tidak dapat mencapai sesuatu; 3) ajarkan mereka bahwa kesalahan akan selalu terjadi dan merupakan bagian alami dari kehidupan, dan tidak membiarkan kesalahan mengalahkan semangat mereka untuk lebih baik lagi; 4) mendaftarkan anak-anak dalam kegiatan ekstrakurikuler untuk memberikan mereka kepercayaan diri yang dibutuhkan dalam memimpin orang-orang; 5) belajar bijaksana terhadap uang; 6) belajar mengambil keputusan; 7) kegiatan berkebun di taman/sekolah; 8) membawa anak ke tempat kerja; serta 9) pembinaan agama.

2. Saran

Konsep kepemimpinan sangat perlu ditanamkan sejak dini pada siswa sekolah dasar. Pendidikan kepemimpinan ini bukan merupakan sebuah proses instan melainkan perlu diintegrasikan dalam kegiatan di dalam kelas ataupun di luar kelas. Peranan orang tua/guru sangat vital, orang tua/guru dituntut untuk mempunyai pemahaman tentang pendidikan kepemimpinan ini. Selanjutnya, orang tua/guru harus mampu mengemas kegiatan yang dapat menjadi sarana pengembangan kepemimpinan ini. Guru pun dituntut mampu membuat situasi kelas yang dapat mengarahkan sikap dan perilaku siswa kepada pengembangan jiwa kepemimpinan mereka. Komunikasi haruslah dibangun secara intensif dengan anak, kemudian pribadi guru juga diharapkan mampu menjadi role model bagi siswa.

\section{Daftar Pustaka}

Al-Bukhari Muhammad Bin Ismail Abu Abdullah. Shahih Bukhori. t.tp: daarut thuqinnajah: $1422 \mathrm{H}$. 
Ellinor, L., \& Gerard, G. (1998). Dialogue: Rediscover the transforming power of conversation. New York: Wiley.

Elmore, Tim, Dr. (2001). Nutiring the Leader Within Your Child. Thomas Nelson Inc., A Tennessee Corporation, 501 Nelson Place P.O. Box 141000, Nashville, TN 37214-1000.

Kessie, Zane Jared. (2016). Leadership Qualities: Teaching Kids to be Leaders. [Online]. Tersedia: https://kindredbond.com/parenting/Le adership-Qualities-Teaching-Kids-to-beLeaders.

Mitchell, Price, Marilyn. (2011). Mistakes Improve Childrens Learning. [Online]. Tersedia: https://www.psychologytoday.com/blo $\mathrm{g} /$ themomentyouth/201109/mistakesimprove-childrens-learning.

Puspitasari, Wina Dwi. (2016). Implementasi Nilai-Nilai Demokrasi di Sekolah Dasar. Repository Prosiding Seminar Nasional Pendidikan Dasar. Volume 2, 244-249.

Puspitasari, Wina Dwi. (2018). Implementasi Metode Hypnoteaching untuk Meningkatkan Hasil Belajar Siswa Sekolah Dasar. Jurnal Cakrawala Pendas. 4, (1).

Rodiyana, Roni. (2015). Pengaruh Penerapan Strategi Pembelajaran Inkuiri Terhadap Kemampuan Berpikir Kritis dan Kreatif Siswa SD. Jurnal Cakrawala Pendas. 1, (1), 34-43.

Rodiyana, Roni. (2016). Penerapan Model Quantum Teaching untuk Meningkatkan Verbal-Linguistik Siswa pada Pembelajaran IPS. Jurnal Cakrawala Pendas. 2, (2).

Rodiyana, Roni. (2016). Growing Democratic Leadership In Elementary Scholl. Proceeding The 3rd Summit Meeting on Education International Seminar. Vol. 1 (Cet. 1).
Rodiyana, Roni. (2018). Pengaruh Penerapan Strategi Quantum Learning terhadap Motivasi Belajar dan Pemahaman Konsep Siswa. Jurnal Cakrawala Pendas. 4, (2), 45-57.

Rodiyana, Roni. (2018). Penerapan Metode Pembelajaran VCT (Value Clarification Technique) untuk Meningkatkan Sikap Demokratis Siswa dalam Pembelajaran PKn di Sekolah Dasar. Jurnal Cakrawala Pendas. 5, (1), 8-18.

Seidman, D. (2007). How: Why how we do anything means everything. Hoboken, $\mathrm{NJ}$ : Wiley.

Sondang, P. Siagian. (1994). Organisasi, Kepemimpinan, Perilaku Administrasi. Jakarta: CV. Haji Mas Agung.

Wiersma, B. (2010). The power of professionalism. Los Altos, CA: Ravel Media.

Yukl, Gary. (2010). Kepemimpinan dalam Organisasi, Edisi Kelima. Jakarta: PT. Indeks. 